\title{
EFEKTIVITAS PENYELESAIAN PELANGGARAN ADMINISTRATIF PEMILIHAN UMUM BERDASARKAN UNDANG-UNDANG NOMOR 7 TAHUN 2017
}

\section{EFFECTIVENESS OF ADMINISTRATIVE INFRACTION SETTLEMENT ON GENERAL ELECTION BASED ON LAW NUMBER 7, 2017}

\author{
Evi Noviawati dan \\ Mamay Komariah
}

Program Studi Ilmu Hukum, Fakultas Hukum, Universitas Galuh.

Korespondensi : Evi Noviawati, Tel. 081320394973

e-mail : evinoviawati76@gmail.com
Jurnal Living Law, Vol. 11, No. 2, 2019 hlm. 140151

\begin{abstract}
The Elections (Elections) in Indonesia is a process of democratization to elect national leaders and people's representatives who are elected directly by the people. The process of organizing the General Election is carried out through the stages stipulated in the Election Commission Regulation. One of the stages that must be passed in the holding of elections is the implementation of campaigns that are part of the political education of the community. In the implementation of an election campaign, election participants can form a campaign team that is responsible for the technical implementation of the campaign. Election administrative violations often occur in the stages of the campaign carried out by election participants which can consequently be detrimental to the election organizers and fellow election participants. Every settlement of election administrative violations can be decided by the Election Supervisory Body (Bawaslu) no later than 7 (seven) working days after the findings and reports are received and registered and then recommended to the KPU for further action. In reality on the ground, there are still many cases of election administrative violations that cannot be resolved due to several obstacles faced, namely the difficulty of finding the reporting party and the limited time in the process of filing reports and findings.
\end{abstract}

Keywords: Settlement; administrative violation; election

\begin{abstract}
Abstrak : Pemilihan Umum (Pemilu) di Indonesia merupakan proses demokratisasi untuk memilih pemimpin bangsa dan perwakilan rakyat yang dipilih secara langsung oleh rakyat. Proses penyelenggaraan Pemilihan Umum dilaksanakan melalui tahapan-tahapan yang ditetapkan dalam Peraturan Komisi Pemilihan Umum. Salah satu tahapan yang harus dilalui dalam penyelenggaraan pemilu adalah pelaksanaan kampanye yang merupakan bagian dari pendidikan politik masyarakat. Dalam pelaksanaan kampanye Pemilu, peserta pemilu dapat membentuk tim kampanye yang bertanggungjawab atas pelaksanaan teknis penyelenggaraan kampanye. Pelanggaran administratif pemilu seringkali terjadi dalam tahapan kampanye yang dilakukan oleh peserta pemilu yang akibatnya dapat merugikan penyelenggara pemilu maupun sesama peserta pemilu. Setiap penyelesaian pelanggaran administratif pemilu dapat diputus oleh Badan Pengawas Pemilu (Bawaslu) paling lama 7 (tujuh) hari kerja setelah temuan dan laporan diterima dan diregistrasi dan kemudian direkomendasikan kepada KPU untuk ditindaklanjuti. Pada kenyataannya di lapangan, masih banyak kasus pelanggaran administratif pemilu yang tidak dapat diselesaikan karena adanya beberapa kendala yang dihadapi yakni sulitnya menemukan pihak pelapor dan sempitnya waktu dalam proses pengajuan laporan dan temuan.
\end{abstract}

Kata Kunci : Penyelesaian; pelanggaran administratif; pemilu 


\section{PENDAHULUAN}

Bangsa Indonesia merupakan salah satu negara yang menganut demokrasi sebagai sistem pemerintahannya. Dengan merujuk kepada sejarah beberapa negara yang berjaya dengan konsep demokrasi, elite politik serta pendahulu bangsa yang menggagas sistem pemerintahan yang menentukan bahwa demokrasi sesuai dengan karakter bangsa Indonesia yang toleran.

Demokrasi merupakan suatu pola pemerintahan dimana kekuasaan untuk memerintah berasal dari mereka yang diperintah. Masyarakat diberikan wewenang untuk menentukan pengambilan keputusan. Legitimasi pemerintah merupakan kemauan rakyat yang memilih dan mengontrolnya. Rakyatlah yang memilih wakil-wakilnya dengan bebas dan melalui mereka ini pemerintahnya.

Perjalanan demokrasi di Indonesia mengalami beberapa kali perubahan sistem demokrasi dalam pemilu, rakyat selalu berharap bahwa dengan perubahan tersebut dapat ditemukan suatu bentuk ideal dari sistem pemilu di tanah air. Metode penyaluran pendapat rakyat yang berdaulat dalam sistem demokrasi dapat dilaksanakan secara langsung (direct democracy) maupun tidak langsung (indirect democracy) atau sering disebut dengan sistem demokrasi perwakilan (representative democracy). Mekanisme penyaluran aspirasi rakyat secara langsung merupakan wujud kedaulatan rakyat dan sesuai dengan sistem ketatanegaraan di Indonesia. Metode penyaluran pendapat secara langsung dapat dilakukan melalui cara-cara sebagai berikut:

a) Pemilihan Umum;

b) Referendum;

c) Prakarsa;

d) Plebisit;

e) Recall;

f) Mogok Kerja;

g) Unjuk Rasa; dan

h) Pernyataan pendapat melalui pers bebas.
Sedangkan metode penyaluran pendapat rakyat secara tidak langsung dapat dilakukan oleh lembaga perwakilan rakyat atau parlemen.

Pemilu merupakan salah satu bentuk dan cara yang paling nyata untuk melaksanakan demokrasi. Jika demokrasi diartikan sebagai pemerintahan dari, oleh, dan untuk rakyat sesuai yang dinyatakan Abraham Lincoln, maka cara yang paling tepat untuk menentukan pemerintahan dilakukan melalui sistem pemilihan umum. Pemilihan umum merupakan salah satu perwujudan hak asasi warga negara yang sangat prinsipiil, karena dalam pelaksanaan hak asasi adalah suatu keharusan pemerintah untuk melaksanakan pemilu dengan memberikan kebebasan serta perlindungan kepada setiap rakyat untuk menentukan pilihannya. Oleh karena itu pemilu adalah suatu syarat yang mutlak bagi negara demokrasi untuk melaksanakan kedaulatan rakyatnya.

Pemilihan Umum (Pemilu) di Indonesia diselenggarakan berdasarkan ketentuan Pasal 22E Undang-Undang Dasar Negara Republik Indonesia Tahun 1945 yang kemudian diatur lebih lanjut dalam Undang-Undang Negara Republik Indonesia Nomor 07 Tahun 2017 tentang Pemilihan Umum.

Pemilu didefinisikan sebagai sarana kedaulatan untuk memilih anggota Dewan Perwakilan Rakyat, anggota Dewan Perwakilan Daerah, Presiden dan Wakil Presiden serta anggota Dewan Perwakilan Rakyat Daerah Provinsi maupun Kabupaten/Kota yang dilaksanakan secara asas langsung, umum, bebas, rahasia, jujur dan adil dalam Negara Kesatuan Republik Indonesia berdasarkan Pancasila dan Undang-Undang Dasar Negara Republik Indonesia Tahun 1945.

Pemilu diselenggarakan oleh penyelenggara pemilu yang terdiri dari Komisi Pemilihan Umum (KPU), Badan Pengawas Pemilu (Bawaslu) dan Dewan Kehormatan Pengawas Pemilu (DKKP) yang dilaksanakan secara berkala yaitu 5 
(lima) tahun sekali. KPU mempunyai kewajiban untuk melaksanakan semua tahapan-tahapan penyelenggaraan pemilu secara tepat waktu. Sedangkan tugas Bawaslu adalah mengawasi pelaksanaan tahapan Penyelenggaraan Pemilu yang dilaksanakan oleh KPU. Dibentuknya DKPP bertujuan untuk memeriksa dan memutus aduan dan/atau laporan adanya dugaan pelanggaran kode etik yang dilakukan oleh anggota KPU, anggota KPU provinsi, anggota, KPU KabupatenfKota, anggota Bawaslu, anggota Bawaslu Provinsi dan anggota Bawaslu Kabupaten/Kota.

Salah satu tahapan penyelenggaraan pemilu adalah tahapan kampanye Pemilu. Tahapan ini merupakan bagian dari pendidikan politik masyarakat yang dilaksanakan secara bertanggung jawab oleh pelaksana kampanye dan diikuti oleh peserta karnpanye. Berdasarkan ketentuan Pasal 275 Ayat (1) Undang-Undang Negara Republik Indonesia Nomor 7 Tahun 2017 tentang Pemilu menyatakan bahwa Kampanye Pemilu dapat dilakukan melalui metode kampanye antara lain:

a. Pertemuan terbatas;

b. Pertemuan tatap muka;

c. Penyebaran bahan Kampanye Pemilu kepada umum;

d. Pemasangan alat peraga di tempat umum;

e. Media sosial;

f. Iklan media massa cetak, media massa elektronik, dan internet;

g. Rapat umum;

h. Debat Pasangan Calon tentang materi kampanye Pasangan Calon; dan

i. Kegiatan lain yang tidak melanggar larangan Kampanye, Pemilu dan ketentuan peraturan perundangundangan.

Objek Pelanggaran Administratif Pemilu adalah perbuatan atau tindakan yang melanggar tata cara, prosedur, atau mekanisme yang berkaitan dengan administrasi pelaksanaan Pemilu dalam setiap tahapan Penyelenggaraan Pemilu. Contoh kasus yang sering terjadi dalam tahap kampanye adalah Pemasangan Alat
Peraga Kampanye (APK) yang seringkali menyisakan berbagai permasalahan yang dianggap sebagai pelanggaran administratif pemilu. Alat Peraga Kampanye (APK) yang ukurannya tidak sesuai dengan Peraturan Komisi Pemilihan Umum (PKPU) yang telah ditetapkan, menggunakan fasilitas pemerintah sebagai area pemasangan Alat Peraga Kampanye, dan penggunaan tempat ibadah sebagai sarana kampanye, seakan menjadi hal yang lumrah karena hal-hal tersebut seringkali tidak masuk dalam pelanggaran administratif pemilu.

Berdasarkan uraian di atas, banyaknya dugaan pelanggaran administratif pemilu yang tidak dapat ditindaklanjuti adalah berkaitan dengan efektivitas penyelesaian pelanggaran administratif pemilu berdasarkan Undang-Undang Republik Indonesia Nomor 7 Tahun 2017 tentang pemilihan umum. Kendala-kendala yang dihadapi dalam pelaksanaan penyelesaian pelanggaran administratif pemilu dan upaya yang dilakukan oleh penyelenggara pemilu dalam penyelesaian pelanggaran administratif pemilu

\section{PEMBAHASAN}

Penyelesaian

Pelanggaran Administratif Pemilhan Umum diatur dalam Undang-Undang Republik Indonesia Nomor 7 Tahun 2017 tentang Pemiihan Umum. Kemudian diatur lebih lanjut dalam Keputusan Badan Pengawas Pemilihan Umum. Berdasarkan Keputusan Badan Pengawas Pemilihan Umum Republik Indonesia Nomor 8 Tahun 2018 tentang Penyelesaian Pelanggaran Administratif Pemilihan Umum menyatakan bahwa yang dimaksud dengan Pelanggaran Pemilu adalah tindakan yang bertentangan dengan ketentuan peraturan perundang-undangan terkait Pemilu. Sedangkan yang dimaksud dengan Pelanggaran Administratif Pemilu adalah perbuatan atau tindakan yang melanggar tata cara, prosedur, atau mekanisme yang berkaitan dengan administrasi pelaksanaan Pemilu dalam setiap tahapan penyelenggaraan Pemilu. Pelanggaran Administratif Pemilu yang 
terjadi secara Terstruktur, Sistematis, dan Masif yang selanjutnya disebut Pelanggaran Administratif Pemilu TSM adalah perbuatan atau tindakan yang melanggar tata cara, prosedur, atau mekanisme yang berkaitan dengan administrasi pelaksanaan Pemilu dalam setiap tahapan penyelenggaraan Pemilu, dan/atau Pasangan Calon, calon anggota DPR, DPD, DRRD Provinsi, DPRD Kabupaten/Kota, menjanjikan dan/atau memberikan uang atau materi lainnya untuk mempengaruhi penyelenggara Pemilu dan/atau Pemilih yang terjadi secara tersruktur, sistematis, dan masif.

\section{A. WEWENANG MEMUTUS LAPORAN DUGAAN PELANGGARAN ADMINISTRATIF PEMILU DAN DUGAAN PELANGGARAN ADMINISTRATIF PEMILU TSM}

1. Bawaslu, Bawaslu Provinsi, Bawaslu Kabupaten/Kota, dan Panwaslu Luar Negeri mempunyai kewenangan untuk menerima, memeriksa, mengkaji, dan memutus dugaan Pelanggaran Administratif Pemilu sesuai dengan tempat terjadinya pelanggaran;

2. Panwaslu Kecamatan berwenang untuk menerima, memeriksa, mengkaji, dan membuat rekomendasi atas hasil kajiannya mengenai dugaan Pelanggaran Administratif Pemilu kepada Pengawas Pemilu secara berjenjang;

3. Panwaslu Kelurahan/Desa mempunyai kewenangan untuk menerima dan menyampaikan dugaan Pelanggaran Administratif Pemilu kepada Panwaslu Kecamatan;

4. Pengawas TPS berwenang untuk menyampaikan keberatan terhadap dugaan pelanggaran, kesalahan dan/atau penyimpangan administrasi pemungutan dan penghitungan suara;

5. Bawaslu berwenang menerima, memeriksa, mengkaji, dan memutus laporan dugaan Pelanggaran Administratif Pemilu TSM terhadap calon anggota DPR, DPD, dan DPRD serta Pasangan Calon;

6. Dalam melaksanakan kewenangannya, Bawasl u dapat membentuk majelis pemeriksa di Bawaslu Provinsi untuk menerima dan memeriksa laporan dugaan Pelanggaran Administratif Pemilu TSM.

\section{B. MAJELIS PEMERIKSA}

Badan Pengawas Pemilu (Bawaslu) membentuk Majelis Pemeriksa dalam penyelesaian Pelanggaran Administratif Pemilu dan Pelanggaran Administratif Pemilu TSM yang berjumlah paling sedikit 3 (tiga) orang yang berasal dari Ketua dan Anggota Bawaslu ditetapkan dengan Surat Keputusan Ketua Bawaslu.

Majelis pemeriksa dalam memeriksa, mengadili, mengkaji dan memutus dugaan Pelanggaran Administratif Pemilu dan Pelanggaran Administratif Pemilu TSM dibantu oleh:

a. 1 (satu) orang sekretaris pemeriksa

Sekretaris pemeriksa dapat berasal dari pejabat struktural Pegawai Negeri Sipil pada Sekretariat Jenderal Bawaslu atau Pejabat Struktural Pegawai Negeri Sipil pada Sekretariat Bawaslu Provinsi. Sedangkan Sekretaris pemeriksa di Bawaslu Kabupaten/Kota merupakan Sekretaris Bawaslu Kabupaten/Kota atau Pegawai Negeri Sipil pada Sekretariat Bawaslu Kabupaten/Kota yang ditetapkan dengan keputusan Ketua Bawaslu, Ketua Bawaslu Provinsi, atau Ketua Bawaslu Kabupaten/Kota.

b. 1 (satu) orang notulen.

Notulen merupakan staf pada Sekretariat Jendral Bawaslu, staf pada Sekretariat Bawaslu Provinsi, atau Staf pada Sekretariat Bawaslu Kabupaten/Kota. Yang ditetapkan dengan keputusan Ketua Bawaslu, Ketua Bawaslu Provinsi, atau Ketua Bawaslu Kabupaten/Kota.

Majelis pemeriksa dilarang berkomunikasi dengan Pelapor, terlapor, 
saksi, dan ahli terkait pelanggaran yang sedang diperiksa di luar proses pemeriksaan penyelesaian Pelanggaran Administratif Pemilu dan Pelanggaran Administratif Pemilu TSM. Begitu juga dengan Asisten pemeriksa, sekretaris pemeriksa, notulen dilarang berkomunikasi dengan Pelapor, terlapor, saksi, dan ahli di luar sidang pemeriksaan. Asisten pemeriksa, sekretaris pemeriksa, dan notulen wajib menjaga dan merahasiakan hasil pemeriksaan dan/atau materi putusan sebelum dibacakan oleh majelis pemeriksa secara terbuka.

\section{OBJEK}

\section{ADMINISTRATIF PELANGGARAN PEMILU TSM}

\section{PELANGGARAN PEMILU ADMINISTRATIF}

Yang menjadi objek pelanggaran administratif pemilu adalah perbuatan atau tindakan yang melanggar tata cara, prosedur, atau mekanisme yang berkaitan dengan administrasi pelaksanaan Pemilu dalam setiap tahapan Penyelenggaraan Pemilu.

Sedangkan objek Pelanggaran Administratif Pemilu TSM terdiri atas :

a. Perbuatan atau tindakan yang melanggar tata cara, prosedur, atau mekanisme yang berkaitan dengan administrasi pelaksanaan Pemilu dalam setiap tahapan Penyelenggaraan Pemilu yang terjadi secara terstruktur, sistematis, dan masif; dan/atau

b. Perbuatan atau tindakan menjanjikan dan/atau memberikan uang atau materi lainnya untuk mempengaruhi penyelenggara Pemilu dan/atau Pemilih yang terjadi secara terstruktur, sistematis, dan masif.

\section{PELAPOR DAN TERLAPOR}

Pelapor dugaan Pelanggaran Administratif Pemilu yaitu Warga Negara Indonesia yang mempunyai hak pilih, Peserta Pemilu dan/atau Pemantau Pemilu. Selain Pelapor, ada juga pihak terlapor dugaan Pelanggaran Administratif Pemilu, yaitu antara lain :

a. Calon anggota DPR;

b. Calon anggota DPD;

c. Calon anggota DPRD Provinsi;

d. Calon anggota DPRD Kabupaten/Kota;

e. Pasangan Calon;

f. Tim kampanye; dan/atau

g. Penyelengara Pemilu.

Pihak terlapor dugaan Pelanggaran Administratif Pemilu TSM yaitu :

a. Calon anggota DPR;

b. Calon anggota DPD;

c. Calon anggota DPRD Provinsi;

d. Calon anggota DPRD Kabupaten/Kota; dan/atau

e. Pasangan Calon;

\section{E. TEMUAN DAN LAPORAN PELANGGARAN ADMINISTRATIF PEMILU DAN PELANGGARAN ADMINISTRATIF PEMILU TSM}

Pelanggaran Administratif Pemilu berasal dari Temuan atau Laporan Pelanggaran Pemilu dan Pelanggaran Administratif Pemilu TSM. Yang dimaksud dengan Temuan Pelanggaran Administratif Pemilu dan Pelanggaran Administratif Pemilu TSM adalah hasil pengawasan Pengawas Pemilu yang terdapat dugaan Pelanggaran Administratif Pemilu berdasarkan keputusan rapat pleno Pengawas Pemilu yang kemudian ditetapkan sebagai temuan dugaan Pelanggaran Administratif atau Pelanggaran Administratif Pemilu TSM Pemilu paling lama 7 (tujuh) hari sejak ditemukan dugaan pelanggaran.

Temuan Bawaslu Kabupaten/Kota disampaikan kepada Bawaslu Provinsi atau Temuan Bawaslu Provinsi disampaikan kepada Bawaslu yang diselesaikan melalui pemeriksaan secara terbuka. Penyampaian Temuan memuat paling sedikit :
a. Identitas Pengawas Pemilu yang menemukan;
b. Identitas terlapor;
c. Waktu dan tempat persitiwa;
d. Bukti dan saksi; 
e. Uraian Peristiwa; dan

f. Hal yang diminta untuk diputuskan.

Upaya lain dugaan pelanggaran administratif Pemilu adalah berdasarkan Laporan dugaan Pelanggaran Administratif Pemilu yang disampaikan oleh pelapor. Laporan dugaan Pelanggaran Administratif Pemilu disampaikan kepada Bawaslu, Bawaslu Provinsi, atau Bawaslu Kabupaten/Kota secara tertulis dalam bahasa Indonesia dan memenuhi syarat formil dan syarat materil laporan. Sedangkan laporan dugaan Pelanggaran Administratif Pemilu TSM disampaikan kepada Bawaslu, atau Bawaslu Provinsi secara tertulis dalam bahasa Indonesia dan memenuhi syarat formil dan syarat materil laporan.

Laporan dugaan Pelanggaran Administratif Pemilu dan Pelanggaran Administratif Pemilu TSM disampaikan paling lama 7 (tujuh) hari kerja sejak diketahui terjadinya dugaan Pelanggaran Administratif Pemilu Pelanggaran Administratif Pemilu TSM .

Syarat formil Laporan dugaan Pelanggaran Administratif Pemilu maupun Pelanggaran Administratif Pemilu TSM memuat antara lain :

a. Identitas Pelapor yang terdiri atas :

1. Nama;

2. Alamat;

3. Nomor telepon atau faksimili; dan

4. Fotokopi kartu tanda penduduk elektronik atau surat keterangan kependudukan dari Dinas Kependudukan dan Catatan Sipil setempat; dan

b. Identitas terlapor terdiri atas :

1. Nama;

2. Alamat; dan

3. Kedudukan atau status dalam penyelenggaraan Pemilu.

Sedangkan syarat materil laporan dugaan Pelanggaran Administratif Pemilu memuat antara lain :

a. Obyek pelanggaran yang dilaporkan yang disertai :

1. Waktu peristiwa;

2. Tempat peristiwa;
3. Saksi;

4. Bukti lainnya; dan

5. Riwayat/uraian peristiwa; dan

b. Hal yang diminta untuk diputuskan.

Laporan dugaan Pelanggaran

Administratif Pemilu TSM disertai paling sedikit 2 (dua) alat bukti dengan ketentuan

a. Untuk pemilihan anggota DPR, pelanggaran terjadi paling sedikit 50\% (lima puluh persen) dari jumlah daerah kabupaten/kota dalam daerah pemilihan, atau paling sedikit 50\% (lima puluh persen) kecamatan dalam 1 (satu) daerah kabupaten/kota, atau gabungan daerah kabupaten/kota dalam daerah pemilihan;

b. Untuk pemilihan anggota DPD, pelanggaran terjadi paling sedikit 50\% (lima puluh persen) dari jumlah daerah kabupaten/kota dalam daerah pemilihan daerah provinsi;

c. Untuk Pemilihan Presiden dan Wakil Presiden, pelanggaran terjadi paling sedikit 50\% (lima puluh persen) dari jumlah daerah provinsi di Indonesia;

d. Untuk pemilihan anggota DPRD Provinsi, pelanggaran terjadi paling sedikit 50\% (lima puluh persen) dari jumlah daerah kabupaten/kota dalam daerah pemilihan, atau paling sedikit 50\% (lima puluh persen) dari jumlah Kecamatan dalam 1 (satu) daerah kabupaten/kota dalam daerah pemilihan;

e. Untuk pemilihan anggota DPRD Kabupaten/Kota, pelanggaran terjadi paling sedikit 50\% (lima puluh persen) dari jumlah kecamatan dalam 1 (satu) daerah kabupaten/kota, atau paling sedikit 50\% (lima puluh persen) dari jumlah kelurahan/desa dalam daerah pemilihan, atau gabungan kelurahan/desa dalam daerah pemilihan; dan/atau

f. Pelanggaran terjadi di luar ketentuan sebagaimana diatur dalam huruf a sampai dengan huruf e yang secara langsung mempengaruhi hasil Pemilu dan perolehan hasil suara terbanyak 
calon anggota DPR, DPD, Pasangan Calon, calon anggota DPRD Provinsi, atau calon anggota DPRD Kabupaten/Kota.

Laporan dugaan Pelanggaran Administratif Pemilu dapat disampaikan melalui Sekretariat Jenderal Bawaslu, Sekretariat Bawaslu Provinsi, atau Sekretariat Bawaslu Kabupaten/Kota. Sedangkan Laporan dugaan Pelanggaran Administratif Pemilu TSM dapat disampaikan melalui Sekretariat Jenderal Bawaslu atau Sekretariat Bawaslu Provinsi.

\section{F. PEMBUKTIAN}

Majelis Pemeriksa akan memutus Pelanggaran Administratif Pemilu paling sedikit memenuhi 2 (dua) alat bukti yang sah. Alat bukti dimaksud berupa:

a. Keterangan saksi;

Alat bukti keterangan saksi merupakan keterangan yang diberikan oleh seseorang yang melihat, mendengar secara langsung dan/atau mengalami terjadinya perbuatan atau peristiwa Pelanggaran Administratif Pemilu.

b. Surat atau tulisan;

Alat bukti surat atau tulisan terdiri atas : a. dokumen hasil pengawasan Pengawas Pemilu; dan/atau b. dokumen tertulis lainnya yang relevan dengan fakta.

c. Petunjuk;

Alat bukti petunjuk merupakan perbuatan, kejadian atau keadaan yang karena persesuaiannya, baik antara yang satu dengan yang lain, maupun dengan pelanggaran itu sendiri, menandakan bahwa telah terjadi suatu Pelanggaran Administratif Pemilu.

d. Dokumen elektronik;

Alat bukti dokumen elektronik merupakan setiap informasi elektronik yang dibuat, diteruskan, dikirimkan, diterima, atau disimpan dalam bentuk analog, digital, elektromagnetik, optikal, atau sejenisnya, yang dapat dilihat, ditampilkan, dan/atau didengar melalui komputer atau sistem elektronik, termasuk tulisan, suara, gambar, peta, rancangan, foto atau sejenisnya, huruf, tanda, angka, kode akses, simbol atau perforasi yang memiliki makna atau arti atau dapat dipahami oleh orang yang mampu memahaminya.

e. Keterangan Pelapor atau keterangan terlapor dalam sidang pemeriksaan;

Alat bukti keterangan Pelapor atau merupakan keterangan Pelapor atau terlapor yang disampaikan secara langsung atau melalui kuasanya dalam sidang pemeriksaan laporan Pelanggaran Administratif Pemilu.

f. Keterangan ahli.

Alat bukti keterangan ahli merupakan keterangan yang disampaikan oleh seseorang sesuai dengan kompetensi dan keahliannya dalam sidang pemeriksaan.

Bawaslu, Bawaslu Provinsi, atau Bawaslu Kabupaten/Kota memutuskan laporan Pelanggaran Administratif Pemilu dengan mempertimbangkan alat bukti dalam sidang pemeriksaan diputuskan dalam rapat pleno pengambilan keputusan yang bersifat tertutup yang kemudian dibacakan dalam sidang yang bersifat terbuka untuk umum. Hasil putusan kemudian akan direkomendasikan kepada KPU untuk ditindaklanjuti.

\section{G. SANKSI}

Sanksi terhadap terlapor/pelaku Pelanggaran Administratif Pemilu adalah:

a. Perbaikan administrasi terhadap tata cara, prosedur, atau mekanisme sesuai dengan ketentuan peraturan perundang-undangan;

b. Teguran tertulis;

c. Tidak diikutkan pada tahapan tertentu dalam penyelenggaraan Pemilu; dan/atau

d. Sanksi administratif lainnya sesuai dengan ketentuan dalam undangundang mengenai Pemilu.

Sedangkan sanksi terhadap terlapor/pelaku yang terbukti melakukan 
tindakan Pelanggaran Administratif Pemilu TSM berupa pembatalan sebagai calon anggota DPR, DPD, DPRD Provinsi, DPRD Kabupaten/Kota, atau Pasangan Calon.

\section{H. TINDAKLANJUT PELANGGARAN PEMILU DAN LAPORAN
ADMINISTRATIF PELANGGARAN ADMINISTRATIF PEMILU TSM}

$\begin{aligned} & \text { Bawaslu, Bawaslu Provinsi, } \\ & \text { Bawaslu } \\ & \text { Kabupaten/Kota } \\ & \text { akan }\end{aligned}$
Pelanggaran Administratif Pemilu atau
Pelanggaran Administratif Pemilu TSM
dengan memberikan nomor temuan dan
dicatatkan dalam buku register temuan
dugaan Pelanggaran Administratif Pemilu
yang kemudian akan dilakukan
pemeriksaan pendahuluan.

Petugas penerima dokumen laporan memeriksa kelengkapan administrasi laporan beserta lampirannya dan materi laporan Pelapor. Apabila dokumen laporan telah lengkap, petugas penerima mengeluarkan tanda terima berkas dengan menggunakan formulir model ADM-3 untuk laporan Pelanggaran Administratif Pemilu atau Pelanggaran Adminitratif Pemilu TSM. Apabila laporan sudah lengkap, Petugas penerima memberikan nomor laporan dan mencatatkan pada buku register laporan. Akan tetapi pabila laporan belum lengkap dan terdapat perbaikan materi laporan, Pelapor melengkapi dan memperbaiki paling lama 3 (tiga) hari kerja sejak dokumen laporan disampaikan oleh Pelapor. Apabila Pelapor tidak melengkapi laporan dalam jangka waktu yang telah ditetapkanmaka Bawaslu, Bawaslu Provinsi, atau Bawaslu Kabupaten/Kota tidak meregister laporan tersebut dan menuangkannya dalam status laporan. Sehingga laporan yang tidak diregister tidak dapat dilanjutkan ke tahap pemeriksaan.

Bawaslu, Bawaslu Provinsi, atau Bawaslu Kabupaten/Kota mengumumkan status laporan di papan pengumuman dan/ atau laman resmi Bawaslu, Bawaslu
Provinsi, atau Bawaslu Kabupaten/Kota dan akan menyampaikan surat pemberitahuan kepada Pelapor tentang laporan yang tidak diregister dengan menggunakan formulir model ADM-5 untuk laporan Pelanggaran Administratif Pemilu atau Pelanggaran Administratif Pemilu TSM.

\section{PROSES PELANGGARAN PEMILU DAN \\ PEMERIKSAAN ADMINISTRATIF ADMINISTRATIF PEMILU TSM}

\section{Pemeriksaan Pendahuluan}

Majelis pemeriksa melakukan pemeriksaan pendahuluan atas kelengkapan dan keabsahan dokumen Temuan atau Laporan dugaan Pelanggaran Administratif Pemilu atau Pelanggaran Administratif Pemilu TSM dengan keterpenuhan syarat formil dan syarat materil berkas laporan, kewenangan untuk menyelesaikan laporan dugaan Pelanggaran Administratif Pemilu atau Pelanggaran Administratif Pemilu TSM, kedudukan atau status Pelapor dan terlapor dan tenggang waktu Temuan atau laporan dugaan Pelanggaran Administratif Pemilu.

Dalam melakukan pemeriksaan pendahuluan, majelis pemeriksa dapat mengundang Pelapor untuk hadir dalam pemeriksaan pendahuluan. Hasil pemeriksaan pendahuluan Temuan atau Laporan dugaan Pelanggaran Administratif Pemilu akan diputuskan dalam rapat pleno Majelis Pemeriksa.

Rapat pleno Majelis Pemeriksa menetapkan putusan hasil pemeriksaan pendahuluan Temuan atau laporan dugaan Pelanggaran Administratif Pemilu atau Pelanggaran Administratif Pemilu TSM terdiri atas :

a. Temuan atau laporan dugaan Pelanggaran Administratif Pemilu atau Pelanggaran Administratif Pemilu TSM tidak dapat diterima dan tidak 
ditindaklanjuti karena tidak memenuhi syarat; atau

b. Temuan atau laporan dugaan Pelanggaran Administratif Pemilu atau Pelanggaran Administratif Pemilu TSM diterima dan ditindaklanjuti dengan sidang pemeriksaan.

Dalam hal pemeriksaan pendahuluan yang dilakukan terhadap laporan dugaan Pelanggaran Administratif Pemilu TSM, majelis pemeriksa provinsi menyampaikan hasil pemeriksaan kepada Bawaslu untuk diputuskan dalam rapat pleno. Hasil keputusan rapat pleno dituangkan ke dalam putusan pendahuluan yang kemudian akan disampaikan kepada majelis pemeriksa provinsi.

Sekretaris pemeriksa memberitahukan kepada Pelapor dan terlapor jadwal sidang pembacaan putusan hasil pemeriksaan pendahuluan. Pembacaan putusan hasil akan dibacakan secara terbuka dan dapat dihadiri oleh Pelapor dan terlapor. Pembacaan putusan hasil pemeriksaan pendahuluan dugaan Pelanggaran Administratif Pemilu TSM dilakukan oleh majelis pemeriksa provinsi, pembacaan harus dihadiri oleh Bawaslu. Dalam hal Pembacaan putusan hasil pemeriksaan pendahuluan dugaan Pelanggaran Administratif Pemilu TSM tidak dihadiri Bawaslu, majelis pemeriksa provinsi dapat membacakan penetapan hasil pemeriksaan pendahuluan. Putusan hasil pemeriksaan sebagaimana dimaksud dalam Pasal 43 disampaikan kepada Pelapor secara tertulis dan diumumkan melalui papan pengumuman dan/atau laman resmi Bawaslu, Bawaslu Provinsi, atau Bawaslu Kabupaten/Kota paling lama 1 (satu) hari setelah pembacaan. Dalam hal putusan menyatakan laporan dugaan Pelanggaran Administratif Pemilu atau Pelanggaran Administratif Pemilu TSM diterima, majelis pemeriksa menindaklanjuti dengan sidang pemeriksaan dan menentukan jadwal sidang pemeriksaan.

\section{Sidang Pemeriksaan}

Sekretaris pemeriksa membuat surat pemberitahuan sidang pemeriksaan kepada Pelapor dan terlapor paling lama 1 (satu) hari sebelum sidang pemeriksaan yang isinya memuat :

a. Jadwal sidang pemeriksaan; dan

b. Udangan untuk menghadiri sidang pemeriksaan, melalui surat tercatat, kurir, surat elektronik, atau faksimile.

Surat pemberitahuan kepada terlapor disertai dengan dokumen laporan dugaan Pelanggaran Administratif Pemilu atau Pelanggaran Administratif Pemilu TSM yang telah diregistrasi. Sidang pemeriksaan pertama dilaksanakan paling lama 1 (satu) hari setelah jadwal sidang disampaikan kepada Pelapor dan terlapor. Pemeriksaan Pelanggaran Administratif Pemilu atau Pelanggaran Administratif Pemilu TSM dilaksanakan melalui tahapan :

a. Pembacaan materi laporan dari Pelapor atau penemu;

b. Tanggapan/jawaban terlapor; c. pembuktian; d. kesimpulan pihak Pelapor atau penemu dan terlapor; dan e. putusan.

Pemeriksaan dihadiri Pelapor dan terlapor. Dalam hal Pelapor dan/atau terlapor tidak hadir pada sidang pemeriksaan pertama, Bawaslu memanggil Pelapor, dan/atau terlapor, untuk hadir pada sidang pemeriksaan berikutnya. Apabila Pelapor dan/atau terlapor sudah dipanggil secara patut dan layak namun tidak hadir 2 (dua) kali berturut-turut, sidang pemeriksaan dilanjutkan tanpa kehadiran Pelapor dan/atau terlapor. Pelapor membacakan materi laporannya pada sidang pemeriksaan pertama dan Terlapor menyampaikan dan membacakan tanggapan/jawaban atas materi laporan Pelapor pada sidang berikutnya.

Pembuktian dilakukan pemeriksaan terhadap :

a. Keterangan saksi;

b. Surat atau tulisan;

c. Petunjuk;

d. Dokumen elektronik;

e. Keterangan terlapor dalam sidang pemeriksaan; dan/atau 


\section{f. Keterangan ahli.}

Majelis pemeriksa dapat memanggil lembaga terkait untuk dimintai keterangan dalam sidang pemeriksaan untuk membuat terang dan jelas suatu peristiwa yang terkait dengan laporan berupa keterangan secara lisan dan/atau tertulis. Apabila pemeriksaan memerlukan keterangan dari ahli, saksi, dan/atau lembaga terkait, majelis pemeriksa dapat melakukan pemanggilan sesuai dengan kebutuhan atau berdasarkan usulan terlapor dan/atau Pelapor. Pemanggilan saksi, ahli atau lembaga terkait menggunakan surat pemberitahuan dan panggilan sidang pemeriksaan. Saksi atau ahli sebelum menyampaikan keterangan diambil sumpah dan selanjutnya menandatangani berita acara Sumpah. Saksi, Ahli, atau lembaga terkait menyampaikan keterangan berkaitan dengan pokok laporan atau jawaban terhadap laporan. Pelapor dan terlapor dapat mengajukan pertanyaan dan/atau memberikan tanggapan terhadap keterangan saksi, ahli, atau lembaga terkait. Pelapor dan terlapor dapat menyampaikan kesimpulan dalam bentuk tertulis atau lisan.

\section{Putusan}

1. Bawaslu memutuskan laporan dugaan Pelanggaran Administratif Pemilu TSM dengan mempertimbangkan alat bukti yang dikemukakan dalam pemeriksaan.

2. Bawaslu, Bawaslu Provinsi, atau Bawaslu Kabupaten/Kota memutuskan laporan Pelanggaran Administratif Pemilu dengan mempertimbangkan alat bukti dalam sidang pemeriksaan.

3. Putusan Bawaslu, Bawaslu Provinsi, atau Bawaslu Kabupaten/Kota diputuskan dalam rapat pleno pengambilan keputusan yang bersifat tertutup.

4. Putusan dibacakan dalam sidang yang bersifat terbuka untuk umum.
5. Putusan akan ditandatangani oleh ketua dan anggota majelis pemeriksa, serta sekretaris pemeriksa.

6. Apabila putusan Bawaslu/Bawaslu Provinsi/Bawaslu Kabupaten/Kota menyatakan laporan Pelanggaran Administratif Pemilu terbukti, amar putusan berbunyi, "MEMUTUSKAN", serta :

a. Menyatakan terlapor, terbukti secara sah dan meyakinkan melakukan Pelanggaran Administratif Pemilu;

b. Memerintahkan kepada KPU, KPU Provinsi, atau KPU Kabupaten/Kota untuk melakukan perbaikan administrasi terhadap tata cara, prosedur, atau mekanisme pada tahapan Pemilu sesuai dengan ketentuan peraturan perundangundangan;

c. Memberikan teguran tertulis kepada terlapor;

d. Memerintahkan kepada KPU, KPU Provinsi, atau KPU Kabupaten/Kota agar terlapor untuk tidak diikutkan pada tahapan Pemilu dalam penyelenggaraan Pemilu; dan/atau

e. Memberikan sanksi administratif lainnya kepada terlapor sesuai dengan ketentuan undang-undang mengenai Pemilu.

7. Putusan Bawaslu, Bawaslu Provinsi, atau Bawaslu Kabupaten/Kota menyatakan laporan tidak terbukti, amar putusan berbunyi, "MEMUTUSKAN", serta menyatakan terlapor tidak terbukti secara sah dan meyakinkan melakukan perbuatan melanggar tata cara, prosedur, atau mekanisme pada tahapan Pemilu sesuai dengan ketentuan peraturan perundang-undangan.

8. Putusan Bawaslu menyatakan laporan Pelanggaran Administratif Pemilu TSM terbukti, amar putusan berbunyi, "MEMUTUSKAN", serta:
a. Menyatakan terlapor, terbukti secara sah dan meyakinkan 
melakukan

Pelanggaran

Administratif Pemilu berupa perbuatan menjanjikan dan/atau memberikan uang atau materi lainnya untuk mempengaruhi penyelenggara Pemilu dan/atau Pemilih yang terjadi secara Tersruktur, Sistematis, dan Masif;

b. Merekomendasikan kepada KPU untuk membatalkan terlapor sebagai calon anggota DPR/DPD atau Pasangan Calon;

c. Merekomendasikan kepada KPU untuk memerintahkan KPU Provinsi membatalkan terlapor sebagai calon anggota DPRD Provinsi; atau

d. Merekomendasikan kepada KPU untuk memerintahkan KPU Kabupaten/Kota untuk membatalkan, terlapor sebagai calon anggota DPRD Kabupaten/Kota.

9. Putusan Bawaslu menyatakan laporan Pelanggaran Administratif Pemilu TSM tidak terbukti, amar putusan berbunyi, "MEMUTUSKAN", serta menyatakan terlapor calon anggota DPR/DPD/DPRD Provinsi/DPRD Kabupaten/Kota/Pasangan Calon tidak terbukti secara sah dan meyakinkan melakukan perbuatan menjanjikan dan/atau memberikan uang atau materi lainnya untuk mempengaruhi penyelenggara Pemilu dan/atau Pemilih yang terjadi secara tersruktur, sistematis, dan masif.

10. Putusan Bawaslu dibacakan secara terbuka dan dibuka untuk umum, serta dapat dihadiri oleh Pelapor dan terlapor.
11. Salinan putusan akan disampaikan kepada Pelapor dan terlapor paling lama 1 (satu) hari sejak putusan dibacakan.

12. Putusan yang menyatakan terlapor terbukti melakukan Pelanggaran Administratif Pemilu TSM, salinan putusan Bawaslu, Bawaslu Provinsi, atau Bawaslu Kabupaten/Kota disampaikan kepada KPU, KPU Provinsi, atau KPU Kabupaten/Kota.

\section{KESIMPULAN}

Banyaknya pelanggaran administratif pemilu yang tidak dapat ditindaklanjuti dan diselesaikan disebabkan adanya beberapa kendala yang dihadapi oleh penyelenggara Pemilu antara lain harus terpenuhinya unsur-unsur temuan atau laporan dugaan pelanggaran administratif Pemilu yang sering kali sulit untuk dipenuhi terutama dalam mencari pelapor. Selain itu kurangnya waktu yang disediakan dalam pengajuan temuan atau laporan dugaan pelanggaran administratif pemilu yaitu paling lama 7 (tujuh) hari sejak diketahui terjadinya dugaan administratif Pemilu. Upaya yang dilakukan penyelenggara Pemilu dalam hal ini Badan Pengawas Pemilu (Bawaslu) adalah dengan mengoptimalisai fungsi pengawasan terhadap tahapan-tahapan penyelenggaraan Pemilu. Sehingga Penulis beranggapan bahwa pada saat ini penyelesaian pelanggaran administratif pemilu berdasarkan Undang-Undang Negara Republik Indonesia Nomor 7 Tahun 2017 belum efektif dilaksanakan.

\section{DAFTAR PUSTAKA}

Jimly Asshiddiqie, Pokok-Pokok Hukum tata Negara Indonesia-Pasca Reformasi (Jakarta: PT. Bhuana Ilmu Populer, 2015)

Miriam Budiarjo, Dasar-Dasar Ilmu Politik (Jakarta: PT Gramedia Pustaka Utama, 2008)

Titik Triwulan Tutik, Kontruksi Hukum Tata Negara Indonesia Pasca Amandemen UUD 1945 (Jakarta: Kencana, 2011) 
Undang-Undang Dasar Negara Republik Indonesia Tahun 1945

Undang-Undang Negara Republik Indonesia Nomor 7 Tahun 2017 tentang Pemilihan Umum

Keputusan Badan Pengawas Pemilihan Umum Republik Indonesia Nomor 8 Tahun 2018 tentang Penyelesaian Pelanggaran Administratif Pemilihan Umum

Seminar Nasional Hukum Universitas Negeri Semarang Volume 4 Nomor 2 Tahun 2018. 